\title{
Does German Foreign Direct Investment Lead to Job Losses at Home?
}

\author{
By Yama Temouri* and Nigel L. Driffield
}

\begin{abstract}
This paper provides firm-level evidence on the labour demand effects of outward investments using a panel of multinationals (MNEs) based in Germany. Distinguishing the type of investments and the location of subsidiaries around the world between 1997 and 2008, our evidence shows that for both the manufacturing and services sector the expansion of employment abroad does not occur at the detriment of employment at home. The analysis is extended to see whether outward FDI causes average wage cuts for workers employed in the German parent firm. Our findings indicate no clear average wage effects due to outward FDI. Given that domestic MNEs are seen to play an important role in the growth potential for an economy, these findings are somewhat re-assuring from a policy point of view.
\end{abstract}

Keywords:

JEL Classifications:

\section{Introduction}

Given the widespread national media coverage and public debate, which is focussed largely on the negative effects of outsourcing and offshoring, the question of whether German MNEs relocate employment abroad to the detriment of employment at home is an important political issue and high on the policy agenda (see for example, German Federal Ministry of Economics and Technology 2007). This empirical question does not only concern German policy makers, but many others in the developed countries. Whether outward FDI acts to displace or is complementary to domestic employment has been the subject of a large number of empirical studies, particularly in the United States (Mankiw, 2004; Mankiw and Swagel, 2006). In fact, recent empirical evidence for the US is not conclusive which in turn makes it difficult for policy-makers to devise any type of response to the growing phenomenon of internationalisation (Harrison and McMillan, 2007).

* Corresponding author: Yama Temouri, Economics and Strategy Group, Aston Business School, Aston Triangle, Birmingham, B4 7ET, United Kingdom; email: temoury1@aston. ac.uk. 
Since the beginning of the 1990s, German outward FDI stocks have risen six fold and throughout this period the volume of outward FDI has been twice the amount of inward FDI, as shown in Figure 1. Indeed, the former amounts to $€ 785$ billion for the year 2005 compared to $€ 390$ billion invested by foreign-owned subsidiaries in Germany. At the beginning of the 1990s, the corresponding figures were $€ 116$ billion and $€ 85$ billion, respectively (Bundesbank, 2007). German MNEs therefore have since considerably strengthened their international position to the extent that Germany is now the third biggest investor after the US and the UK.

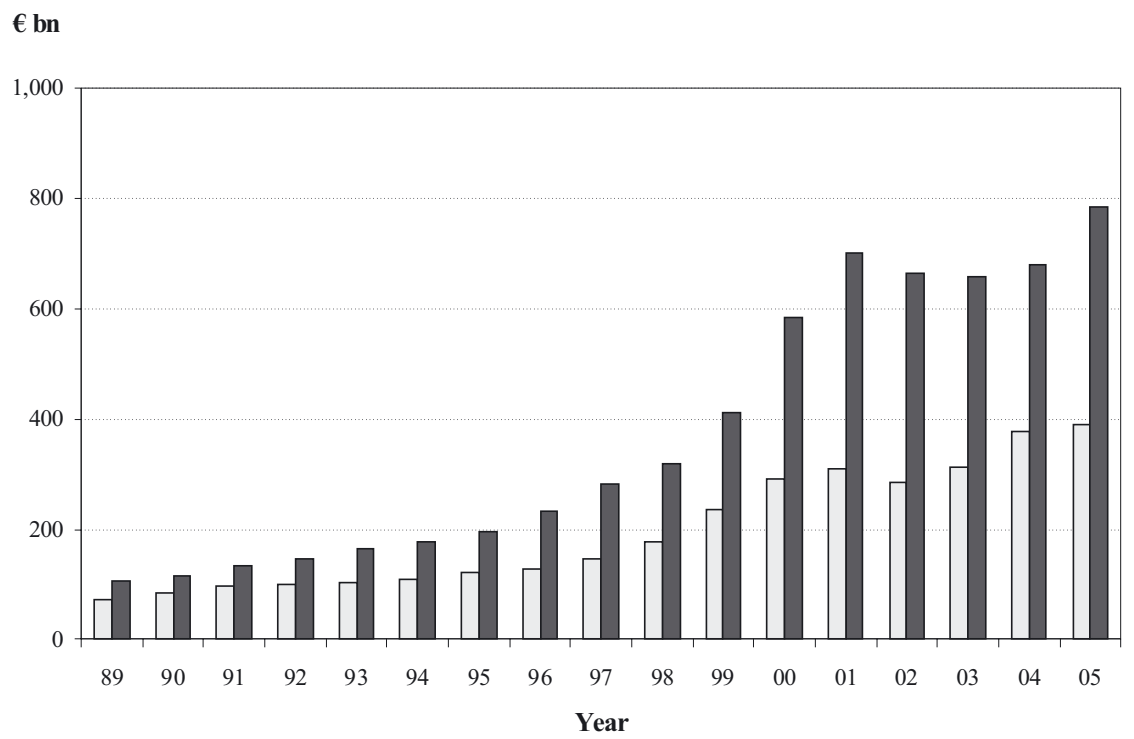

$\square$ Total InwardFDI $\quad \square$ Total OutwardFDI

Source: Bundesbank, 2007.

Figure 1: German FDI Stocks (1989-2005)

This paper provides firm-level evidence on the labour demand effects of outward investment using a panel of multinationals (MNEs) based in Germany. Given that MNEs are seen to play an important role in terms of the growth potential in Germany, it is imperative to see whether their activities are occurring at the detriment of employment and the possible erosion of the skill base. It is also true that most theoretical work in this area has focussed on the competition that western unskilled workers face from their counterparts in developing countries.

The contribution to the existing literature is threefold. Firstly, we analyse the employment effects of outward FDI using a firm level dataset over an eleven year period. Secondly, in line with the theoretical literature this paper particularly highlights the differences between low versus high cost destinations and the type of 
investment undertaken. This is a unique feature of our data set in that it allows us to link a parent firm's domestic operations with its subsidiaries across the world including whether the investment is of a horizontal or vertical nature.

Thirdly, most of the previous studies focus merely on the manufacturing sector, and particularly at only one type of potential offshoring, the relocation of low skill activities ${ }^{1}$. However, the services sector is becoming ever more important, and is potentially at least as heterogeneous as the manufacturing sector, including knowledge-intensive industries as well as more basic functions. These knowledge intensive sectors play an ever more important role in the structure and volume of outward FDI in advanced economies. Figure 3 shows that in 2005, high technology and knowledge intensive industries undertake the majority of German FDI. The biggest German investors are concentrated in the services sector ( 73 percent) mainly in the financial intermediation sector ( 33 percent), followed by the real estate, trade, transportation and communication sector. The manufacturing sector accounts for roughly 25 percent in 2005 and is led by the chemical and car industries followed by the electrical and machinery industries (Bundesbank, 2007). Figure 2 and 3 also show that over the period 1995-2005, German outward FDI from the manufacturing sector has shrunk from 39 percent of the total in 1995 to 25 percent of the total in 2005, while the service sector expanded from 58 percent to 73 percent.

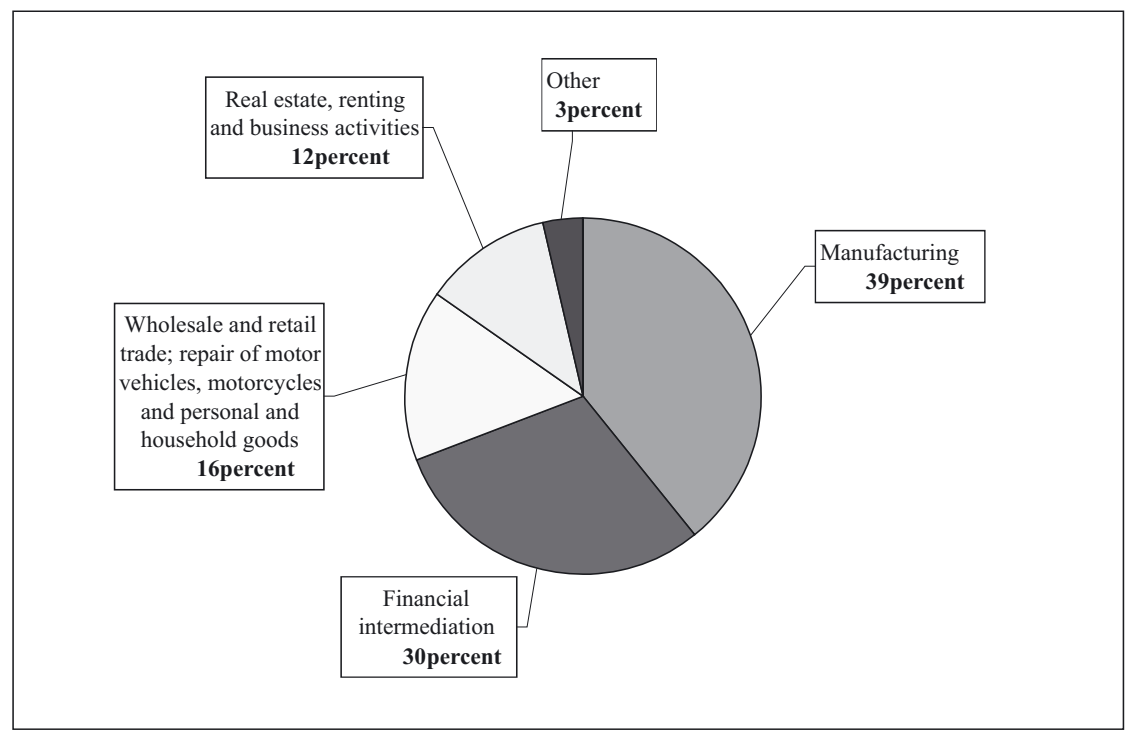

Source: Bundesbank, 2007.

Figure 2: German Outward FDI by Sector in 1995

\footnotetext{
1 This is due to the fact that micro-data for the service sector is not readily available for many countries.
} 


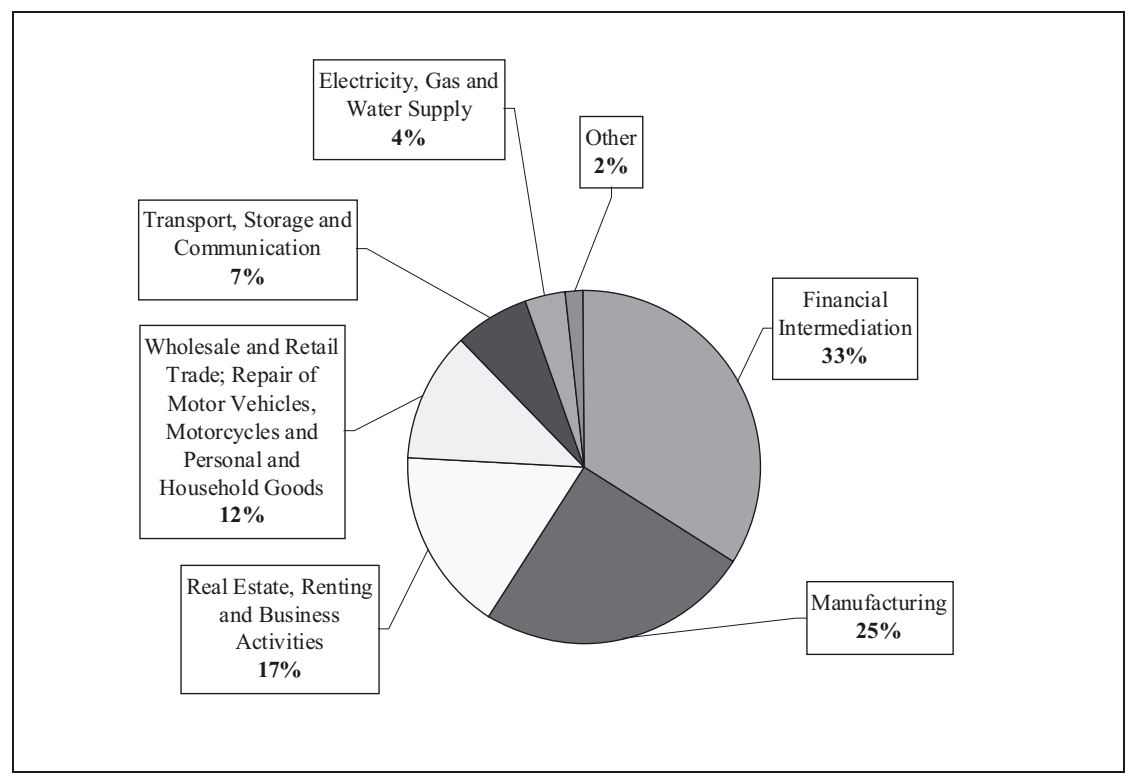

Source: Bundesbank, 2007.

Figure 3: German Outward FDI by Sector in 2005

The rest of the paper is organised as follows. Section 2 gives an overview of the arguments in previous empirical studies on the relationship between outward FDI and labour demand, with particular focus on Germany. Section 3 explains the empirical model. Section 4 offers a description of the data and some descriptive statistics. Section 5 presents the results and section 6 concludes.

\section{Previous Empirical Evidence}

The empirical work which has investigated the role of FDI on labour demand has until recently only considered inward FDI (see Conyon et al. 2004 for effects on overall UK wage rates; Driffield et al., 2009; Blonigen and Slaughter 2001, for the impact of FDI on wage inequality in the UK and USA, respectively).

However, in recent years outward FDI has attracted more attention ${ }^{2}$. In particular, the relationship between outward FDI and home country employment has been the subject of some high profile empirical studies, particularly in the United States (Mankiw 2004; Mankiw and Swagel 2006). However, this empirical evidence is rather inconclusive which in turn makes it difficult to define a specific policy agenda in relation to outward FDI and labour market adjustments (Harrison and McMillan 2007).

2 For an overview see Lipsey (2002) and Barba Navaretti and Venables (2004). 
Of primary concern in the literature hitherto has been the outsourcing of intermediate inputs, in particular the production tasks performed by lower skilled workers, to foreign countries which offer lower wages compared to the home country. This is shown to impact on labour demand by reducing the demand for lower skilled labour (Feenstra and Hanson 1999). However, the demand for skilled labour is enhanced by any increase in technological capability of the firm at the expense of less skilled workers. Recently, Hijzen et al. (2005) estimating a system of variable factor demands report that for the UK over the period 1982 to 1996 outsourcing has had a detrimental impact upon unskilled labour (see also Taylor and Driffield 2005 for the UK and Machin and Van Reenen 1998). ${ }^{3}$

Brainard and Riker (2001) use matched US parent-subsidiary data for 1983 1992 and find small substitution effects between parent and subsidiary employment. Subsidiary employment in both high and low income countries substitute for employment in the US ${ }^{4}$. Blomström et al. (1997) find that US MNEs relocate their labour-intensive activities to subsidiaries in developing countries which are not found in the case of Swedish MNEs. However, Braconier and Ekholm (2000) find some evidence that home country employment in Swedish MNEs is a substitute for employment in subsidiaries in other high-income host countries for the period $1970-1994$.

Barba Navaretti et al. (forthcoming) examine how outward FDI to cheap labour countries affect home activities for a sample of French and Italian firms that turn multinational between the years 1993 to 2000 . They use propensity score matching techniques and find no evidence of a negative effect for both countries of outward investments to cheap labour countries. Italian MNEs enhance their efficiency and show a positive effect on output and employment. For France they find a positive effect on the size of domestic activity. The same methodology is used on employeremployee data by Becker and Muendler (2007) in the case of Germany. They show that German MNEs would shed more labour if it was prevented from internationalising compared to national rival firms ${ }^{5}$.

3 It is possible that technological change and outsourcing of production are not independent processes. Indeed, Marin (2006) finds that less technologically advanced firms, as measured by research and development intensity, have a higher probability of outsourcing to Eastern Europe.

4 In an earlier study Riker and Brainard (1997) focus only on the employment in the foreign subsidiaries find that US-owned subsidiary employment located in developing countries are complementary to subsidiary employment in industrialised countries. In other words, an expansion in subsidiaries employment in the former region is accompanied with an increase in subsidiary employment in industrialised countries. However, they also show that labour competes across subsidiaries in the same region in countries with a similar skill-level in their workforce.

5 Other studies using this methodology are Egger and Pfaffermayr (2003) for Austria, Barba Navaretti and Castellani (2004) for Italy, Debeare et al. (2006) for Korea and Hijzen et al (2006) for France. 
Marin (2004) uses Austrian and German firm-level data from 1997-2001, collected through surveys, and finds that Eastern Enlargement leads to small job losses in both countries. The argument put forward is that jobs in Eastern Europe do not compete with jobs in Austria and Germany in the case of vertical investments. Low cost jobs in subsidiaries in Eastern Europe reduce production costs and induce Austrian and German MNEs to produce more and demand more labour which in turn makes them stay competitive.

Marin (2006) also examines what factors influence the outsourcing decision of German and Austrian firms, in particular considering the impacts from Eastern European countries. The more labour intensive the production process the higher the probability of outsourcing occurring outside the firm to an independent input supplier from Eastern Europe, suggesting that labour costs matter.

Konings and Murphy (2006) match MNEs with their subsidiaries, both located in Europe, to test for employment substitution in response to wage differentials. Their findings are surprising in that they suggest substitutability only for North European MNEs and their subsidiaries which are also located in North Europe. No significant effects are found for subsidiaries located in South or Central and Eastern Europe from which they conclude that competition from low-wage countries does not represent a threat to parent firm employment. This latter result confirms findings presented by Barba Navaretti et al. (forthcoming).

\section{The Model and Estimation}

The main form of analysis employed in this paper focuses on labour demand functions augmented by measures of outward FDI along regional and industry lines (Brakonier and Ekholm, 2000; Konings and Murphy, 2006). In terms of estimation, the number of employees of the parent firm (in log form) acts as the dependent variable in an attempt to identify whether outward FDI stimulates or hinders labour demand at home. However, any changes in labour demand may be associated with a change in the average wage received by the employees of the parent firm. For example, an expansion in outward FDI might exert downward pressure on wages in any future wage negotiations between parent firms and labour unions, leaving parent employment constant. Equally, wages may rise as a result of increased competitiveness and profitability of the parent firm due to outward investments. Therefore, a second set of estimations is performed on average wages as the dependent variable for each specification.

As indicated previously, an important contribution of this paper is the classification of outward FDI flows. We group outward investments in several distinct ways. The reason for doing this is to ascertain whether certain effects are driven by location or type of investments. The literature on FDI makes a distinction between horizontal and vertical FDI which ex ante would lead one to expect to either be a substitute or to be complementary to activities at home. According to the theory, 
horizontal FDI is likely to have a negative impact on home employment as domestic production for exports is replaced by affiliate production in foreign host countries. However, in the case of so-called export platform $F D I^{v i}$ which is closely related to horizontal FDI, the employment effects for the home country are less clear (Brakonier and Ekholm 2000). According to the theory of vertical FDI, firms take advantage of factor price differentials between countries in an effort to reduce costs and become more efficient. In this case, increased investment abroad is less likely to have a negative effect on home employment. The reason is that gains in overall productivity due to lower costs make firms more competitive which in turn may lead firms to expand total employment within the MNE and the home country.

Following the large literature on employment and wage determination (see for example Brainard and Riker 1997b; Figini and Görg 1999 and Driffield and Girma 2003) we consider two sets of empirical models. The first set is a reduced-form log-linear labour demand model (equation 1) and the second set an equivalent version for average wages (equation 2). Thus the underlying labour demand equations can be specified as:

(1) $L_{i j t}^{P}=\beta_{0}+\beta_{1} L_{i j t-1}^{P}+\beta_{2} Q_{i j t}+\beta_{3}$ Avg.Wage $+\beta_{4} K_{i j t}+\beta_{5} \frac{\sum_{i}^{n} W_{i j t}^{s}}{\sum_{i}^{n} L_{i j t}^{s}}+\beta_{j}+\beta_{c}+\beta_{t}+v_{i t}$

where $L^{P}$ is the $\log$ of employees for firm $i$, industry $j$ and at time $t$; The explanatory variables are lagged employment $\left(L_{i j t-1}^{P}\right)$, output $\left(Q_{i j t}\right)$, the average wage of the parent firm (Avg.Wage) and capital intensity $\left(K_{i j t}\right) \cdot \frac{\sum_{i}^{n} W_{i j t}^{s}}{\sum_{i}^{n} L_{i j t}^{s}}$ represents the average wage of subsidiaries belonging to a particular parent firm. For each model, we specify four specifications. The first specification groups all subsidiaries together, regardless of location and type of investment. The second specification divides the subsidiaries according to their location, namely high versus low income countries. The third specification splits subsidiaries operations by type of investment vis-àvis their parents (i.e. horizontal or vertical). The fourth specification interacts the location terms with the type of investment. $\beta_{j}, \beta_{c}$ and $\beta_{t}$ are industry, country and year dummies respectively and $\mathrm{k}$ stands for the number of lags. Finally, $v_{i t}$ represents the error term.

Similarly, the second sets of equations with average wages as the dependent variable are specified as follows:

(2) $W_{i j t}^{P}=\beta_{0}+\beta_{1} L_{i j t-1}^{P}+\beta_{2} Q_{i j t}+\beta_{3}$ Avg.Wage $+\beta_{4} K_{i j t}+\beta_{5} \frac{\sum_{i}^{n} W_{i j t}^{s}}{\sum_{i}^{n} L_{i j t}^{s}}+\beta_{j}+\beta_{c}+\beta_{t}+v_{i t}$ 
We estimate equation 2 to see whether outward FDI causes average wage cuts for workers in the German parent firm.

\subsection{Econometric Considerations}

It is well known that using OLS will lead to biased results and thus is problematic. Specifically, employment is likely to be simultaneously determined with output and wages which leads to a potential source of endogeneity in the estimation. Thus to estimate equations 1 and 2 we employ the system Generalised Method of Moments (GMM) one-step estimator, outlined in Blundell and Bond (1998) and Bond (2002). In terms of model specification, the Hansen statistic indicates that our instruments are valid and that there is no second order autocorrelation $(\mathrm{AR}(2))$ in the levels equation.

With an issue such as this, the issue of sample selection effects is potentially important. We adopt a relatively standard approach to testing for this, commonly used in the literature (see for example Harris and Robinson 2003). This is to estimate a simple probit model that represents the probability of a firm engaging in outward FDI. The dependent variable is a binary variable that takes the value of 1 if a German firm undertakes outward FDI and 0 if it is not. The lagged change in employment (or wages) acts as explanatory variable, with other controls. There is no apparent relationship between FDI and lagged employment (or wages) changes, suggesting that sample selection effects are not important.

\section{Data}

Our data is taken from the Orbis database, provided commercially by Bureau van Dijk, and covers the period 1997-2008 which includes a total of 2,129 MNEs located in Germany, with 3,477 subsidiaries located across the world. The following two tables show the distribution of MNEs and their subsidiaries by destination and sector and offer some descriptive statistics for them.

We only include firms for which unconsolidated accounts with all variable used in the analysis are available, where we were able to link a particular parent with its subsidiaries. The reason for using unconsolidated accounts is that, unlike consolidated accounts, they represent the domestic activities of firms and not its operations worldwide or an aggregate in the case of owning other companies at home.

A foreign subsidiary is defined as an incorporated enterprise in which more than 50 percent of equity is directly or indirectly owned by the foreign business entity, called the "parent" firm. This threshold is suggested and used for statistical purposes by the $\mathrm{OECD}^{6}$ and is common in the literature (e.g. Ruane and Moore, 
2005). The threshold is considered to represent a meaningful stake and effective voice in the management of the subsidiary by the parent. Using this information our data set allows us to link a parent firm's domestic operations with its subsidiaries across the world.

We classify firms according to their NACE industry classification at the 2-digit level. To assess whether the investment is of a horizontal or vertical nature we use the primary industry code given in the dataset for both the parent and the subsidiary. If a parent and subsidiary have the same 2-digit NACE code, then this is considered a horizontal investment. In all other cases, the investment is seen to be of a vertical nature.

We distinguish FDI in two distinct locations, namely low wage versus high wage economies. To classify low and high income countries we follow the World Bank classification which is also used by other studies, such as Becker et al. (2005) and Harrison and McMillan (2007).

Table 1 shows the distribution of parent and subsidiary firms in the sample by country and region. The majority of parent firms invest in other developed or OECD countries. For example, 73.7 percent of parent firms invest in the EU and 21 percent in North America. This is in line with aggregate figures given by the official statistics of the Bundesbank (2007). Also, 27.3 percent of parent firms invest in Eastern Europe which has become a more attractive place to invest in recent years. The least favourite destinations for MNEs are other Europe, Oceania, Asia, Latin America and Africa showing investment of 9.2 percent, 0.2 percent, 2.3 percent, 6.8 percent and 1.6 percent, respectively. Given the sample, there are more parent firms, on average, from the service sector than the manufacturing sector investing in every region.

Most of the German subsidiaries in the sample are located in other high income countries within the EU (60.5 percent) and North America (12.1 percent). Within Europe the two biggest receivers of German FDI are the UK (23 percent of the EU-15 total) and Austria (22.2 percent of the EU-15 total). Other lesser high income destinations are other Europe (i.e. Norway and Switzerland), Oceania and some high income Asian countries. Subsidiaries in low income countries are concentrated mainly in Eastern Europe (16.9 percent), Latin America (4 percent) as well as Africa ( 0.8 percent) and some low income Asian countries. More broadly, around 77 percent of all subsidiaries are located in high income countries; whereas 23 percent are located in low income countries. The share of subsidiaries which operate in the services sector is again higher than the manufacturing sector.

6 This type of FDI is established in a certain country where the affiliate produces the product/service to be exported to other countries or region. The classic example is US FDI in Ireland destined for the EU market. 
Table 1

Regional Distribution of Subsidiary firms, 1997-2008 (percent)

\begin{tabular}{|c|c|c|c|c|c|c|}
\hline \multirow[t]{2}{*}{ Country/Region } & \multirow[b]{2}{*}{ All firms } & \multirow[b]{2}{*}{ MFG } & \multirow{2}{*}{$\begin{array}{c}\text { Parent } \\
\text { SERV }\end{array}$} & \multicolumn{3}{|c|}{ Subsidiary } \\
\hline & & & & All firms & MFG & SERV \\
\hline \multicolumn{7}{|l|}{ EU-15 } \\
\hline of which & 73.7 & 43.4 & 56.6 & 60.5 & 35.2 & 64.8 \\
\hline United Kingdom & 38.2 & 45.2 & 54.8 & 23.0 & 22.3 & 77.7 \\
\hline Austria & 38.8 & 38.5 & 61.5 & 22.2 & 15.5 & 84.5 \\
\hline Other Europe & 9.2 & 32.3 & 67.7 & 4.5 & 28.1 & 71.9 \\
\hline \multicolumn{7}{|l|}{ Eastern Europe } \\
\hline of which & 27.3 & 43.0 & 57.0 & 16.9 & 37.6 & 62.4 \\
\hline Hungary & 43.0 & 41.4 & 58.6 & 32.1 & 33.2 & 66.8 \\
\hline Poland & 40.8 & 42.8 & 57.2 & 29.6 & 35.7 & 64.3 \\
\hline North America & 21.0 & 55.1 & 44.9 & 12.1 & 44.1 & 55.9 \\
\hline Oceania & 0.2 & 50.0 & 50.0 & 0.1 & 50.0 & 50.0 \\
\hline Asia & 2.3 & 56.3 & 43.8 & 1.2 & 50.7 & 49.3 \\
\hline Latin America & 6.8 & 54.5 & 45.5 & 4.0 & 50.2 & 49.8 \\
\hline Africa & 1.6 & 50.0 & 50.0 & 0.8 & 41.9 & 58.1 \\
\hline
\end{tabular}

Note: MFG -manufacturing; SERV -service sector.

Source: Authors' calculations from Orbis data set.

In terms of the sectoral distribution of parent and subsidiary firms Table 2 shows that 44.9 percent of all parent firms undertaking FDI operate in the manufacturing sector whereas 55.1 percent operate in the service sector. The sample also shows substantial heterogeneity in the type of investments undertaken. Generally, the percentage of parent firms undertaking vertical FDI is higher than the ones investing horizontally. The group of firms investing both horizontally and vertically is the smallest. These investments are located to a higher degree in high wage economies.

The manufacturing parents have 75.4 percent of all their subsidiaries in high wage locations and 24.6 percent in low wage locations. The type of investment of these manufacturing parent firms is to 20.7 percent horizontal, 62.4 percent vertical and 16.9 percent of their investments are both horizontal and vertical in nature. The distribution of subsidiaries according to the type of investments is to a high degree (around $3 / 4$ ) in high wage economies.

The distribution of service parent firms by type of investment and location of subsidiaries is very similar to that of the manufacturing parent firms. For example, 78.6 percent of the subsidiaries are located in high wage economies and 21.4 percent in low wage economies. The type of investment is 31.7 percent horizontal, 47.6 percent vertical and 20.7 percent of their investments are both horizontal and vertical in nature. The distribution of subsidiaries according to the type of investments is again similar with a high degree (around $\mathbf{\square}$ ) in high wage economies. 
Table 2

Sector distribution of parent and subsidiary firms, 1997-2008 (percent)

\begin{tabular}{rccc}
\hline & Parents & \multicolumn{2}{c}{ Subsidiaries } \\
& & High wage & Low wage \\
\hline Manufacturing & & & \\
Of which undertake: & 44.9 & 75.4 & 24.6 \\
Horizontal FDI & 20.7 & 66.1 & 33.9 \\
Vertical FDI & 62.4 & 78.4 & 21.6 \\
Both & 16.9 & 71.9 & 28.1 \\
& & & \\
Services & & & 21.4 \\
Of which undertake: & 55.1 & 78.6 & 21.6 \\
Horizontal FDI & 31.7 & 78.4 & 21.2 \\
Vertical FDI & 47.6 & 78.8 & 20.6 \\
Both & 20.7 & 79.4 & \\
\hline
\end{tabular}

Source: Authors' calculations from Orbis data set.

Table 3 presents summary statistics for selected performance indicators of interest for German MNEs versus non-MNEs. They reveal that German MNEs are on average larger, more capital intensive and have higher sales figures than domestic nonMNEs. For instance, compared to the latter set of firms, MNEs employ, on average, more than ten times the number of employees; have a total wage bill more than four times as much; and are more productive. A variable that captures firm-specific assets, namely intangible assets, also shows a much higher value for MNEs in the sample compared with non-MNEs. Additionally, in terms of financial indicators, MNEs are shown inter alia as having, on average, a cash flow at least ten times that of their domestic counterparts. Also the level of TFP is higher for MNEs than non-MNEs. These differences in characteristics are statistically significant at the 5 percent level. This is consistent with those found by other researchers examining various aspects of globalisation and their effect on firm / plant performance (Wagner, 2006).

Table 3

Summary Statistics for Firms Operating in Germany

\begin{tabular}{|c|c|c|c|c|}
\hline \multirow{3}{*}{ Variable } & \multicolumn{2}{|c|}{ Manufacturing } & \multicolumn{2}{|c|}{ Services } \\
\hline & MNEs & Non-MNEs & MNEs & Non-MNEs \\
\hline & $\begin{array}{c}\text { Mean } \\
\text { (Std. Dev.) }\end{array}$ & $\begin{array}{c}\text { Mean } \\
\text { (Std. Dev.) }\end{array}$ & $\begin{array}{c}\text { Mean } \\
\text { (Std. Dev.) }\end{array}$ & $\begin{array}{c}\text { Mean } \\
\text { (Std. Dev.) }\end{array}$ \\
\hline Number of Employees & $\begin{array}{c}5,310 \\
(25)\end{array}$ & $\begin{array}{c}562 \\
(3,322)\end{array}$ & $\begin{array}{c}6,291 \\
(29,092)\end{array}$ & $\begin{array}{c}466 \\
(1,936)\end{array}$ \\
\hline Sales (US \$ million) & $\begin{array}{c}1,082 \\
>(5,995)\end{array}$ & $\begin{array}{c}59 \\
(654)\end{array}$ & $\begin{array}{c}1,054 \\
(4,281)\end{array}$ & $\begin{array}{l}304 \\
(82)\end{array}$ \\
\hline
\end{tabular}


Table 3 (Continue)

\begin{tabular}{lcccc}
\hline & \multicolumn{2}{c}{ Manufacturing } & \multicolumn{2}{c}{ Services } \\
Variable & MNEs & Non-MNEs & MNEs & Non-MNEs \\
& $\begin{array}{c}\text { Mean } \\
\text { (Std. Dev.) }\end{array}$ & $\begin{array}{c}\text { Mean } \\
\text { (Std. Dev.) }\end{array}$ & $\begin{array}{c}\text { Mean } \\
\text { (Std. Dev.) }\end{array}$ & $\begin{array}{c}\text { Mean } \\
\text { (Std. Dev.) }\end{array}$ \\
\hline Total Wage Bill (US\$ & 268 & 11 & 220 & 54 \\
million) & $(3,406)$ & $(110)$ & $(1,032)$ & $(14)$ \\
Cash Flow (US \$ & 85 & 2 & 108 & 9 \\
million) & $(672)$ & $(48)$ & $(725)$ & $(188)$ \\
Intangibles (US\$ & 78 & 1 & 176 & 4 \\
million) & $(535)$ & $(12)$ & $(2,085)$ & $(424)$ \\
Capital-Labour ratio & 0.7 & 0.3 & 2 & 2 \\
& $(8)$ & $(10)$ & $(14)$ & $(44)$ \\
Capital (US\$ million) & 296 & 6 & 561 & 30 \\
& $(2,381)$ & $(45)$ & $(3,887)$ & $(770)$ \\
Materials (US\$ million) & 597 & 31 & 527 & 230 \\
& $(7,884)$ & $(278)$ & $(2,108)$ & $(61)$ \\
TFP & 4.01 & 3.16 & 4.78 & 3.62 \\
& $(0.57)$ & $(0.56)$ & $(0.96)$ & $(0.77)$ \\
\hline
\end{tabular}

Source: Authors' calculations from Orbis data set.

\section{Results}

The results from the estimation of (1) are reported in tables 4 and 5 for the manufacturing and service sectors respectively. When estimating the labour demand equations, we find that for both the manufacturing and service sector the coefficients on the lag of employment, output, and capital intensity are positive and significant as expected. The coefficient on the wage of the parent is negative and significant which means that as wages increase, own parent employment decreases. The point estimates are also well within the range of those generally found in the literature (e.g. Konings and Murphy 2006).

More importantly, the wage effects of subsidiaries do not seem to have an effect on the German parent firm's own labour demand. Specifications 1 through 4 show very small but insignificant results, regardless of type and location of the subsidiaries. The exception for the manufacturing sector is the negative effect that average wage has on labour demand in other high income countries that are in horizontal subsidiaries (-0.0006). This suggests that while there is competition between labour in high wage countries, the impact on labour demand at the individual firm level is limited.

For the services sector, we neither find any statistically significant coefficients for the four specifications. Only for specification (3) the coefficient for $W^{S-V F D I}$ 
is both positive and significant. Even when interacting the type of investment with its location (specification 4) in order to disentangle possible combined effects estimates of labour demand are insignificant in both sectors.

Table 5 and 7 show the parent wage effects due to outward FDI. The findings show that coefficients on the lag of average wages and labour productivity are positive and highly significant as expected. The effect of outward FDI on average wages is again small and insignificant. However for the manufacturing sector; increased investments due to subsidiary wage reduction in high income countries which are of horizontal nature generate small reductions in wages at home. In the service sector, horizontal investments regardless of location have a positive and significant coefficient, but only at the 10 percent level. This suggests that, rather than facing competition from workers in low income countries, German workers also face competition from similar workers in high income countries. However, as is well understood, Germany has a relatively inflexible labour market, which mitigates against any short run changes. Equally, Germany has powerful labour unions which make it difficult to realize any significant wage reductions. This is also the focus of a recent policy paper by Sapir (2005) which argues that greater labour market reform in countries, such as France and Germany, is essential for greater competitiveness and productivity growth.

One reason for not finding significant and sizeable effects is that firms often undertake both types of investments simultaneously in a number of locations which may have opposing effects. For example, firms which increase their productivity due to cost-savings in low-income countries may expand production and employ more labour not at home but in another high-skilled country. Another possibility is that firms may only increase R\&D-related activity at home complemented with high-skilled workers in a third country. There are a multitude of possibilities for firms in deciding the skill-mix of workers they wish to employ and in what locations. Therefore, in this regard our results are merely an indication of the overall labour demand effects and are likely to be driven by the above mentioned forces.

\section{Conclusion}

This paper investigates the labour demand and wage effects of outward FDI using a panel of German MNEs and their foreign subsidiaries around the world between 1997 and 2008. Overall, our results suggest that in neither manufacturing nor services sector outward FDI leads to a reduction in employment or average earnings in the home country. Given that MNEs in Germany play an important role in terms of growth potential for an economy, these findings are somewhat re-assuring from a policy point of view. We then extend the analysis to see whether outward FDI has any average wage effects on workers employed in the parent firm. One could argue that the lack of any employment contraction at home, following 
especially investment to low income countries, is a result of lower wage demands or even wage cuts at home. However, our findings indicate that there seems to be no clear average wage effect due to outward FDI.

Overall, our evidence presented here is broadly in line with recent empirical work. Barba Navaretti et al. (forthcoming) find no evidence of a negative employment effect for Italian and French MNEs which invest in cheap labour countries. Marin (2004) also reports similar findings with respect to investments in Eastern Europe. However, our positive findings with respect to high income countries for the manufacturing sector are in contrast with Braconier and Ekholm (2000) who find evidence of substitutability between parents and subsidiaries in other high income host countries.

It is important to note a number of significant limitations of the analysis in this paper. One limitation of the data is that it does not allow us to distinguish between the skill composition of the labour force (i.e. whether skilled or unskilled) which would certainly have a consequence on the skill-mix employed by the firm as explained earlier. Secondly, our definition of horizontal and vertical FDI is based on the 2-digit NACE classification. Thus, if the parent and subsidiary operate in the same 2-digit high-tech industry, it is a horizontal investment; in all other cases it is a vertical investment. However, one could go beyond 2-digits to classify horizontal and vertical investments.

It is also possible to sub-divide vertical investments into activities which remain in the manufacturing sector and ones which are in the services sector. However, due to the limited size of our sample this was not possible. Lastly, it would be very informative to test employment effects of FDI destinations, on a country by country basis. However, this is not presently possible, due to the limited number subsidiaries per country and years observed, both for the parent and subsidiary. Nevertheless, the data set we have used in this analysis is rich enough to assemble and test employment effects emanating from German outward investments.

Given the limitations of this research, future research may combine the various investment opportunities by MNEs on a country by country analysis with the skill composition of the labour force to enrich the analysis. It would also be of interest to see whether effects are any different for MNEs from other OECD countries. This seems to be an important avenue of further research to assess the heterogeneous employment effects induced by the expansion and relocation of MNEs around the world. 
Table 4

\section{Effect of Average Subsidiary Wages on Parent Employment (MANUFACTURING)}

\begin{tabular}{|c|c|c|c|c|}
\hline $\begin{array}{l}\text { Dependent Variable: } \\
\text { Parent Firm Employment }\end{array}$ & (1) & (2) & (3) & (4) \\
\hline Employment $_{(t-1)}$ & $\begin{array}{l}0.667 * * * \\
(0.0966)\end{array}$ & $\begin{array}{c}0.699 * * * \\
(0.0734)\end{array}$ & $\begin{array}{c}0.579 * * * \\
(0.126)\end{array}$ & $\begin{array}{c}0.741 * * * \\
(0.093)\end{array}$ \\
\hline Output $_{(t)}$ & $\begin{array}{c}0.247 * * * \\
(0.0666)\end{array}$ & $\begin{array}{c}0.227 * * * \\
(0.0519)\end{array}$ & $\begin{array}{c}0.296 * * * \\
(0.0828)\end{array}$ & $\begin{array}{l}0.200 * * * \\
(0.0662)\end{array}$ \\
\hline Average-Wage $_{(t)}$ & $\begin{array}{c}-0.705 * * * \\
(-0.157)\end{array}$ & $\begin{array}{c}-0.688 * * * \\
(-0.153)\end{array}$ & $\begin{array}{c}-0.744 * * * \\
(-0.159)\end{array}$ & $\begin{array}{c}-0.684 * * * \\
(-0.173)\end{array}$ \\
\hline Capital $_{(t)}$ & $\begin{array}{c}0.0496^{* * *} \\
(0.0186)\end{array}$ & $\begin{array}{l}0.0429 * * * \\
(0.015)\end{array}$ & $\begin{array}{c}0.0654 * * * \\
(0.0251)\end{array}$ & $\begin{array}{c}0.0300^{*} \\
(0.016)\end{array}$ \\
\hline$W^{S}$ & $\begin{array}{l}0.0225 \\
(0.029)\end{array}$ & & & \\
\hline$W^{S-H I C}$ & & $\begin{array}{c}0.00323 \\
(0.00349)\end{array}$ & & \\
\hline$W^{S-L I C}$ & & $\begin{array}{c}0.0000489 \\
(0.00192)\end{array}$ & & \\
\hline$W^{S-H F D I}$ & & & $\begin{array}{c}0.00375 \\
(-0.00398)\end{array}$ & \\
\hline$W^{S-V F D I}$ & & & $\begin{array}{c}0.00576 \\
(-0.00363)\end{array}$ & \\
\hline$W^{S-H F D I \_i n \_H I C}$ & & & & $\begin{array}{c}-0.000606 * * * \\
(-0.000187)\end{array}$ \\
\hline$W^{S-V F D I \_i n \_H I C}$ & & & & $\begin{array}{c}-0.000564 \\
(-0.000479)\end{array}$ \\
\hline$W^{S-H F D I \_i n \_L I C}$ & & & & $\begin{array}{l}-0.000222 \\
(-0.000152)\end{array}$ \\
\hline$W^{S-V F D I \_i n \_L I C}$ & & & & $\begin{array}{l}-0.0000208 \\
(-0.000255)\end{array}$ \\
\hline Industry / Year Dummies & Yes & Yes & Yes & Yes \\
\hline Wald Test (prob. $>$ chi2) & 0.000 & 0.000 & 0.000 & 0.000 \\
\hline AR 1 (p-value) & 0.002 & 0.002 & 0.003 & 0.001 \\
\hline AR 2 (p-value) & 0.162 & 0.154 & 0.160 & 0.385 \\
\hline Hansen test (p-value) & 0.952 & 0.922 & 0.995 & 0.998 \\
\hline Observations & 1,172 & 1,172 & 1,172 & 1,172 \\
\hline
\end{tabular}

$* * *, * *, *$ denote significance at the 1,5 , and 10 percent level, respectively. Note: Robust standard-errors in parentheses. 
Table 5

\section{Effect of Average Subsidiary Wages on Parent Wages (MANUFACTURING)}

\begin{tabular}{|c|c|c|c|c|}
\hline $\begin{array}{l}\text { Dependent Variable: } \\
\text { Average Wage of Parent } \\
\text { Employment }\end{array}$ & (1) & (2) & (3) & (4) \\
\hline 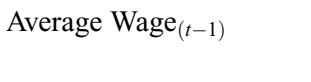 & $\begin{array}{c}0.388^{* * *} \\
(0.133)\end{array}$ & $\begin{array}{c}0.267 * * \\
(0.105)\end{array}$ & $\begin{array}{l}0.242 * \\
(0.134)\end{array}$ & $\begin{array}{l}0.207^{*} \\
(0.126)\end{array}$ \\
\hline Labour productivity $_{(t)}$ & $\begin{array}{c}0.346^{* *} \\
(0.141)\end{array}$ & $\begin{array}{c}0.335^{* * * *} \\
(0.119)\end{array}$ & $\begin{array}{c}0.400^{* *} \\
(0.166)\end{array}$ & $\begin{array}{c}0.330^{* *} \\
(0.145)\end{array}$ \\
\hline$W^{S}$ & $\begin{array}{c}0.0511 \\
(0.0329)\end{array}$ & & & \\
\hline$W^{S-H I C}$ & & $\begin{array}{c}-0.0000678 \\
(-0.00292)\end{array}$ & & \\
\hline$W^{S-L I C}$ & & $\begin{array}{l}0.00154 \\
(0.0017)\end{array}$ & & \\
\hline$W^{S-H F D I}$ & & & $\begin{array}{c}-0.000708 \\
(-0.00354)\end{array}$ & \\
\hline$W^{S-V F D I}$ & & & $\begin{array}{c}0.00297 \\
(0.00341)\end{array}$ & \\
\hline$W^{S-H F D I \_i n \_H I C}$ & & & & $\begin{array}{c}-0.000323 * \\
(-0.00018)\end{array}$ \\
\hline$W^{S-V F D I \_i n \_H I C}$ & & & & $\begin{array}{l}-0.00111^{* *} \\
(-0.000488)\end{array}$ \\
\hline$W^{S-H F D I \_i n \_L I C}$ & & & & $\begin{array}{c}-0.000171 \\
(-0.000148)\end{array}$ \\
\hline$W^{S-V F D I \_i n \_L I C}$ & & & & $\begin{array}{l}-0.000488^{*} \\
(-0.000284)\end{array}$ \\
\hline Industry / Year Dummies & Yes & Yes & Yes & Yes \\
\hline Wald Test (prob. $>$ chi2) & 0.000 & 0.000 & 0.000 & 0.000 \\
\hline AR 1 (p-value) & 0.040 & 0.029 & 0.016 & 0.005 \\
\hline AR 2 (p-value) & 0.476 & 0.590 & 0.716 & 0.887 \\
\hline Hansen test (p-value) & 1.000 & 0.819 & 0.682 & 0.784 \\
\hline Observations & 1,174 & 1,174 & 1,174 & 1,174 \\
\hline
\end{tabular}

$* * *, * *, *$ denote significance at the 1,5 , and 10 percent level, respectively.

Note: Robust standard-errors in parentheses. 
Table 6

\section{Effect of Average Subsidiary Wages on Parent Employment (SERVICES)}

\begin{tabular}{|c|c|c|c|c|}
\hline $\begin{array}{l}\text { Dependent Variable: } \\
\text { Parent Firm Employment }\end{array}$ & (1) & (2) & (3) & (4) \\
\hline Employment $_{(t-1)}$ & $\begin{array}{c}0.859 * * * \\
(0.0702)\end{array}$ & $\begin{array}{c}0.762 * * * \\
(0.0689)\end{array}$ & $\begin{array}{c}0.725^{* * *} \\
(0.0925)\end{array}$ & $\begin{array}{c}0.759 * * * \\
(0.0594)\end{array}$ \\
\hline Output $_{(t)}$ & $\begin{array}{c}0.0680^{* *} \\
(0.0331)\end{array}$ & $\begin{array}{l}0.111 * * * \\
(0.0343)\end{array}$ & $\begin{array}{c}0.132 * * * \\
(0.0445)\end{array}$ & $\begin{array}{c}0.116^{* * *} \\
(0.0302)\end{array}$ \\
\hline Average-Wage $(t)$ & $\begin{array}{c}-0.187 * * \\
(-0.073)\end{array}$ & $\begin{array}{r}-0.261 * * * \\
(-0.0828)\end{array}$ & $\begin{array}{r}-0.286 * * * \\
(-0.0929)\end{array}$ & $\begin{array}{r}-0.259 * * * \\
(-0.0784)\end{array}$ \\
\hline 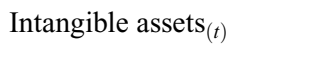 & $\begin{array}{c}0.0372 * * \\
(0.0158)\end{array}$ & $\begin{array}{c}0.0498^{* * *} \\
(0.0149)\end{array}$ & $\begin{array}{c}0.0549^{* * *} \\
(0.0184)\end{array}$ & $\begin{array}{c}0.0527 * * * \\
(0.0138)\end{array}$ \\
\hline$W^{S}$ & $\begin{array}{c}-0.0357 \\
(-0.0618)\end{array}$ & & & \\
\hline$W^{S-H I C}$ & & $\begin{array}{c}0.00312 \\
(0.00439)\end{array}$ & & \\
\hline$W^{S-L I C}$ & & $\begin{array}{l}0.00154 \\
(0.0028)\end{array}$ & & \\
\hline$W^{S-H F D I}$ & & & $\begin{array}{c}-0.00158 \\
(-0.00411)\end{array}$ & \\
\hline$W^{S-V F D I}$ & & & $\begin{array}{c}0.00706^{* *} \\
(0.00357)\end{array}$ & \\
\hline$W^{S-H F D I \_i n \_H I C}$ & & & & $\begin{array}{l}0.000248 \\
(0.00028)\end{array}$ \\
\hline$W^{S-V F D I \_i n \_H I C}$ & & & & $\begin{array}{l}-0.00026 \\
(-0.0002)\end{array}$ \\
\hline$W^{S-H F D I \_i n \_L I C}$ & & & & $\begin{array}{l}-0.00011 \\
(-0.00026)\end{array}$ \\
\hline$W^{S-V F D I \_i n \_L I C}$ & & & & $\begin{array}{c}-0.00016 \\
(-0.00019)\end{array}$ \\
\hline Industry / Year Dummies & Yes & Yes & Yes & Yes \\
\hline Wald Test (prob.>chi2) & 0.000 & 0.000 & 0.000 & 0.000 \\
\hline AR 1 (p-value) & 0.067 & 0.081 & 0.096 & 0.081 \\
\hline AR 2 (p-value) & 0.334 & 0.352 & 0.444 & 0.448 \\
\hline Hansen test (p-value) & 0.643 & 0.911 & 0.899 & 0.883 \\
\hline Observations & 944 & 944 & 944 & 944 \\
\hline
\end{tabular}

$* * *, * *, *$ denote significance at the 1,5 , and 10 percent level, respectively.

Note: Robust standard-errors in parentheses. 
Table 7

\section{Effect of Average Subsidiary Wages on Parent Wages (SERVICES)}

\begin{tabular}{|c|c|c|c|c|}
\hline $\begin{array}{l}\text { Dependent Variable: } \\
\text { Average Wage of Parent } \\
\text { Employment }\end{array}$ & (1) & (2) & (3) & (4) \\
\hline Average Wage $_{(t-1)}$ & $\begin{array}{l}0.225^{* *} \\
(0.0973)\end{array}$ & $\begin{array}{c}0.426 * * * \\
(0.111)\end{array}$ & $\begin{array}{c}0.244^{* *} \\
(0.102)\end{array}$ & $\begin{array}{c}0.343 * * * \\
(0.115)\end{array}$ \\
\hline Labour productivity $_{(t)}$ & $\begin{array}{c}0.322 * * * \\
(0.111)\end{array}$ & $\begin{array}{l}0.115^{* *} \\
(0.0556)\end{array}$ & $\begin{array}{l}0.239 * * \\
(0.0931)\end{array}$ & $\begin{array}{c}0.192 * * * \\
(0.0684)\end{array}$ \\
\hline$W^{S}$ & $\begin{array}{l}0.191 * * \\
(0.0786)\end{array}$ & & & \\
\hline$W^{S-H I C}$ & & $\begin{array}{l}0.00625 \\
(0.0058)\end{array}$ & & \\
\hline$W^{S-L I C}$ & & $\begin{array}{c}0.00261 \\
(0.00403)\end{array}$ & & \\
\hline$W^{S-H F D I}$ & & & $\begin{array}{l}0.00997 * \\
(0.00595)\end{array}$ & \\
\hline$W^{S-V F D I}$ & & & $\begin{array}{c}0.00574 \\
(0.00539)\end{array}$ & \\
\hline$W^{S-H F D I \_i n \_H I C}$ & & & & $\begin{array}{c}-0.000548 \\
(-0.000387)\end{array}$ \\
\hline$W^{S-V F D I \_i n \_H I C}$ & & & & $\begin{array}{l}0.0000710 \\
(0.000371)\end{array}$ \\
\hline$W^{S-H F D I \_i n \_L I C}$ & & & & $\begin{array}{c}-0.000368 \\
(-0.000358)\end{array}$ \\
\hline$W^{S-V F D I \_i n \_L I C}$ & & & & $\begin{array}{c}-0.000239 \\
(-0.000298)\end{array}$ \\
\hline Industry / Year Dummies & Yes & Yes & Yes & Yes \\
\hline Wald Test (prob. $>$ chi2) & 0.000 & 0.000 & 0.000 & 0.000 \\
\hline AR 1 (p-value) & 0.002 & 0.027 & 0.003 & 0.006 \\
\hline AR 2 (p-value) & 0.936 & 0.527 & 0.568 & 0.606 \\
\hline Hansen test (p-value) & 0.863 & 0.529 & 0.930 & 0.984 \\
\hline Observations & 1,016 & 1,016 & 1,016 & 1,016 \\
\hline
\end{tabular}

$* * *, * *, *$ denote significance at the 1,5 , and 10 percent level, respectively.

Note: Robust standard-errors in parentheses. 


\section{References}

Barba Navaretti, G. / Castellani, D. (2004): "Investments Abroad and Performance at Home: Evidence from Italian Multinationals," CEPR Disussion Papers 4284.

Barba Navaretti, G. / Venables, A. (2004): "Multinational Firms in the World Economy," Princeton University Press.

Barba Navaretti, G. / Castellani, D. / Disdier, A. (forthcoming): "How does investing in cheap labour countries affect performance at home? Firm-level evidence from France and Italy," Oxford Economic Papers.

Becker, S. / Muendler, M. A. (2007): “The effect of FDI on job separation,” Discussion Paper Series 1: Economic Studies. Bundesbank, Germany.

Becker, S. / Ekholm, K. / Jäckle, R. / Muendler, M. A. (2005): "Location Choice and Employment Decisions: A Comparison of German and Swedish Multinationals," Review of World Economics 141(4), $693-731$.

Blomström, M. / Fors, G. / Lipsey, R. E. (1997): "Foreign Direct Investment and Employment: Home Country Experience in the United States and Sweden," Economic Journal 107(445): $1787-97$.

Blonigen, B. / Slaughter, M. (2001): "Foreign-Subsidiary Activity and U.S. Skill Upgrading," Review of Economics and Statistics 83(2), 362-79.

Blundell, R. / Bond, S. (1998): "Initial conditions and moment restrictions in dynamic panel data models," Journal of Econometrics 87(1), 115-43.

Bond, S. (2002): "Dynamic Panel Data Models: A Guide to Micro Data Methods and Practice," Cemmap Working Paper CWP09/ 02.

Braconier, H. / Ekholm, K. (2000): "Swedish Multinationals and Competition from High- and Low-Wage Locations," Review of International Economics 8(3), 448-61.

Brainard, S.L./Riker, D. A. (1997): “Are U.S. Multinationals Exporting U.S. Jobs?” NBER Working Paper 5958, National Bureau of Economic Research, Cambridge, Mass.

Brainard, L./Riker, D. (2001): "Are US Multinationals Exporting US Jobs? Globalization and Labour Markets," in Globalization and Labour Markets, edited by D. Greenaway and D. R. Nelson, Cheltenham, UK and Northampton, MA, Edward Elgar.

Conyon, M. / Girma, S. / Thompson, S. / Wright, P. (2004): "Do Wages Rise or Fall Following Merger?," Oxford Bulletin of Economics and Statistics 66(5), 847-62.

Debaere, P. / Lee, H. / Lee, J. (2006): "Does Where you Go Matter? The Impact of Outward Foreign Direct Investment on Multinationals' Employment at Home," CEPR Discussion Paper No. 5737.

Driffield, N. L. / Girma, S. (2003): "Regional Foreign Direct Investment and Wage Spillovers: Plant Level Evidence from the U.K. Electronics Industry," Oxford Bulletin of Economics and Statistics 65(4), $453-74$.

Driffield, N. / Love, J. H.,/ Taylor, K. (2009): "Productivity and Labour Demand Effects of Outward and Inward FDI on UK Industry,” Manchester School 77(2), 171-203.

Applied Economics Quarterly 55 (2009) 3 
Egger, P. / Pfaffermayr, M. (2003): "The Counterfactual to Investing Abroad: An Endogenous Treatment Approach of Foreign Subsidiary Activity," University of Innsbruck Working Paper No. 02.

Figini, P. / Görg, H. (1999): "Multinational companies and wage inequality in the host country: The case of Ireland,” Weltwirtschaftliches Archiv 134(4), 594-612.

Federal Ministry of Economics and Technology (2007): Press release given by Michael Glos and Wolfgang Tiefensee. http: / / www.bmvbs.de/en/Federal-Government-Commissione / Economy-and-investments-,2575.9854 40 / Tiefensee-and-Glos-Activities-.htm

Feenstra, R. / Hanson, G. (1999): "The Impact of Outsourcing and High-Technology Capital on Wages: Estimates for the U.S., 1979-1990," Quarterly Journal of Economics 114(3), $907-40$.

Griffith, R./ Redding, R./ Simpson, H. (2004): "Foreign Ownership and Productivity: New Evidence from the Service Sector and the R\&D Lab," Oxford Review of Economic Policy 20(3), $440-56$.

Harris, R. / Robinson, C. (2003): "Foreign Ownership and Productivity in the United Kingdom. Estimates for UK manufacturing using the ARD," Review of Industrial Organization $22,207-23$.

Harrison, A. / McMillan, M. (2007): “On the links between globalization and poverty,” Journal of Economic Inequality 5(1), 123-34.

Hijzen, A. / Görg, H./ Hine, R. (2005): "International Outsourcing and the Skill Structure of Labour Demand in the United Kingdom,” Economic Journal 115(506), 860-78.

Hijzen, A. / Jean, S. / Mayer, T. (2006): "The Effects at Home of Initiating Production Abroad: Evidence from Matched French Firms," CEPII, manuscript.

Konings, J. / Murphy, A. (2006): "Do Multinational Enterprises relocate employment to LowWage Regions? Evidence from European Multinationals," The Review of World Economics 142(1), 1-20.

Lipsey, R. E. (2002): “Home and host country effects of FDI,” NBER Working Paper 9293.

Machin, S./Van Reenen, J. (1998): "Technology and changes in skill structure: Evidence from seven OECD countries,” Quarterly Journal of Economics 113(4), 1215-44.

Mankiw, N. (2004): "The Economic Report of the President," Council of Economic Advisors, Washington, D. C., February 2004.

Mankiw, N. G./ Swagel, P. (2006): "The Politics and Economics of Offshore Outsourcing," NBER Working Paper 12398.

Marin, D. (2004): "A Nation of Poets and Thinkers: Less so with Eastern Enlargement? Austria and Germany," CEPR Discussion Paper 4358.

Marin, D. (2006): "A New International Division of Labor in Europe: Outsourcing and Offshoring to Eastern Europe," Journal of the European Economic Association 4(2-3), $612-22$.

Organisation for Economic Co-operation and Development (OECD) (1996): "Benchmark Definition of Foreign Direct Investment," third edition, Paris. 
Ruane, F. / Moore, P. (2005): "Taxation and the Financial Structure of Foreign Direct Investment," The Institute for International Integration Studies, Discussion Paper Series 88.

Sapir, A. (2005) "Globalisation and the Reform of European Social Models Background document for the presentation at ECOFIN Informal Meeting in Manchester", 9 September 2005. Available at www.brugel.org

Taylor, K./ Driffield, N. (2005): "Wage inequality and the role of multinationals: evidence from UK panel data," Labour Economics 12(2), 223 - 49.

Wagner, J. (2006): "Exports, foreign direct investment, and productivity: Evidence from German firm-level data," Applied Economics Letters 13(6), 347-349. 